\title{
Collect and treat urban wastewater to fight the pandemic disease of COVID-19 effectively
}

\author{
Author: Prof Dr. Eng. Abdol Aziz Shahraki*, Ph.D., Senior Researcher at Royal Institute of \\ Technology, KTH. School of Architecture and Built Environments. Department of Urban \\ Studies and Environment. Stockholm, Sweden. Email: sharaki@kth.se \\ Researcher ID: https://orcid.org/0000-0002-7211-8230
}

\begin{abstract}
:
This paper presents multidisciplinary and innovative research concerning fighting against coronavirus through wastewater collection and treatment. Studies suggest that coronavirus exists in the wastewaters. Untreated wastewater is proved to spread the virus. Coronavirus is attacking people globally and shrinking the economy. This paper highlights the idea that the coronavirus shall be defeated with the help of wastewater collection and treatment as well. The question addressed by this paper is will communities defeat the coronavirus without well-collected and treated wastewaters? This research aims to display the role of wastewaters in the spread of coronavirus in cities and to require their collection. The methods to achieve the goals are theoretical surveys, case study strategy, mathematical modeling, statistical procedures, forecasting of future, and dialectical discussions. The findings of this research demonstrate the need for carefully collected and treated wastewaters to overcome the coronavirus. This paper gives suitable techniques to collect and treat wastewater such as wastewater stabilization ponds, bacterial reactors, and anaerobic ponds. The innovative idea of this paper, its suggested indicators to select a certain wastewater treatment technique in every city, and its outcome will assist the global community to fight the coronavirus more effectively.
\end{abstract}

\section{Keywords:}

Coronavirus; wastewater treatment techniques; mathematical model; statistical procedures; bacterial reactors, anaerobic ponds

\section{Introduction}

COVID 19 disease is an infectious disease caused by a newly discovered coronavirus [1]. The coronavirus attack on the people of the world came as a surprise. The coronavirus emerged when states that were prioritizing public health care and providing more medical services gave way to governments with policies of austerity and privatization of enterprises [2], [3] and [4]. The coronavirus emerged when the world was proud of its scientific and medical advances in recent 
decades. The world had controlled some dangerous infectious diseases and thought that it would control any other epidemic easily [5]. Also, the coronavirus emerged when class and income differences between social groups and individuals in societies had become much greater than before [6] and [7]. As a result, many people lost access to health products (such as masks, alcohol, disinfectant solutions, etc.), medical devices (such as ventilators, refrigerants, oxygen capsules, etc.), and medicines that help the patient. Worse, local and regional wars and conflicts in parts of the world have taken over the budgets of some militant countries. The governments of those countries have essentially left the people defenseless against the COVID-19 disease. Worst of all, the results of information communication technological advances in the monopoly of unqualified governments have prevented the publication of real statistics on the casualties of COVID-19 disease. The governments filter information concerning widespread damages caused by the virus to the lives and economy of the people [8]. In this situation, problems such as lack of safe drinking water, unclean living environment, and untreated sewage in the streets and alleys of cities have also increased the arrogance of the coronavirus to attack public health [9]. Therefore, as an essential step in the fight against the coronavirus, the collection of wastewaters from the cities and their treatment should be an important project of local administrations, national governments, and international organizations such as WHO and UNDP [10], [11] and [12].

The question is can we defeat the coronavirus without well-collected and treated municipal and household wastewaters? Another question is that in this economic crisis and the urgency of cleaning the environment, which wastewater treatment technique shall we use?

This study aims to show the role of municipal and household wastewaters in the spread of coronavirus in communities. The purpose is also to emphasize the collection and treatment of wastewaters to protect the health of the people of the community. Therefore, in this article, the most appropriate techniques for wastewater collection and treatment will be proposed and analyzed.

The method of this research is field studies with mathematical modeling to show the capacity of wastewaters in the streets of cities in terms of increasing the number of death tolls due to COVID-19 disease. The statistical technique of the trend line is also used to predict death tolls from this disease in future months.

The findings of this study show that those trying to fight the coronavirus cannot overcome the evil virus just in hospitals. Well-collected and treated wastewaters as important factors are required in achieving this victory as well.

\section{Theoretical exploration}

Newly, researchers declared that wastewaters include coronaviruses [13]. Scholars have shown that coronavirus exists in Stockholm's municipal wastewater [14]. In Stockholm's wastewaters, the 
amount of coronavirus has become doubled in recent weeks. It is now reached to the same amount of May 2020 [14]. New findings confirm that wastewater analyzes can warn concerning future virus outbreaks [14]. Stockholm is one of the most advanced cities in the world in terms of wastewater collection and treatment, clean environment, urban infrastructures, and public healthcare system [15]. In countries with unqualified urban administrations and the majority of impoverished people, wastewaters are discharged from households to the sidewalks. The sewage of such cities flows in open streams in the streets and passages. The wastewater is exposed to touch, inhalation, the breath of people, and penetration into the body of humans and living things in society.

Experiences about the COVID-19 disease show that poor people living in neighborhoods polluted with the wastewaters flowing in the streets are more infected or dead than affluent people in clean neighborhoods [16], [17], [18] and [19]. Therefore, well-treated sewage can protect people's health against this disease [20]. Untreated wastewater causes major damage to the environment and human health. Therefore, wastewaters should be treated to decrease the spread of diseases and pollution of water resources [21], [22], [23], [24] and [25].

A procedure to detect viruses in the water distribution systems had been introduced earlier by Chastain "The COVID-10 pandemic gives us an important stimulus to reevaluate health in the context of a circular system that encompasses human and environment in which we live" [26]. We simulate the idea of Chastain to detect the coronavirus and declare as the following: 'The successful transmission of a coronavirus infection might depend on some factors such excreted volume of the wastewater, the latency of the wastewater on the ground, the persistence of the virus, multiplication of the virus, spatial infectivity, and susceptibility of the individuals'.

Urban wastewater contains a range of organic matter, food, chemicals, human waste, and microorganisms. The city's sewage contains human body waste (feces, urine, nails, and hair) as well as water used to wash the toilet. Domestic sewages contain a wide range of chemicals such as detergents, soaps, fats, and possibly various types of pesticides from home gardens and pots. Microscopic organisms capable of causing human diseases are also in the wastewaters [27]. An infected person may become diseased, depending on his or her susceptibility to the COVID-19 disease through geohelminths, human cestode and trematode worms, leptospirosis, and coronavirus itself that are included in the wastewaters. Non-treated wastewaters will increase the incidence and prevalence of new cases of COVID-19 disease in a community that occurs in a specified period and a specified point in the time respectively [28]. Figure 1 exhibits that the trend of the number of daily infected people by the coronavirus is additive. 


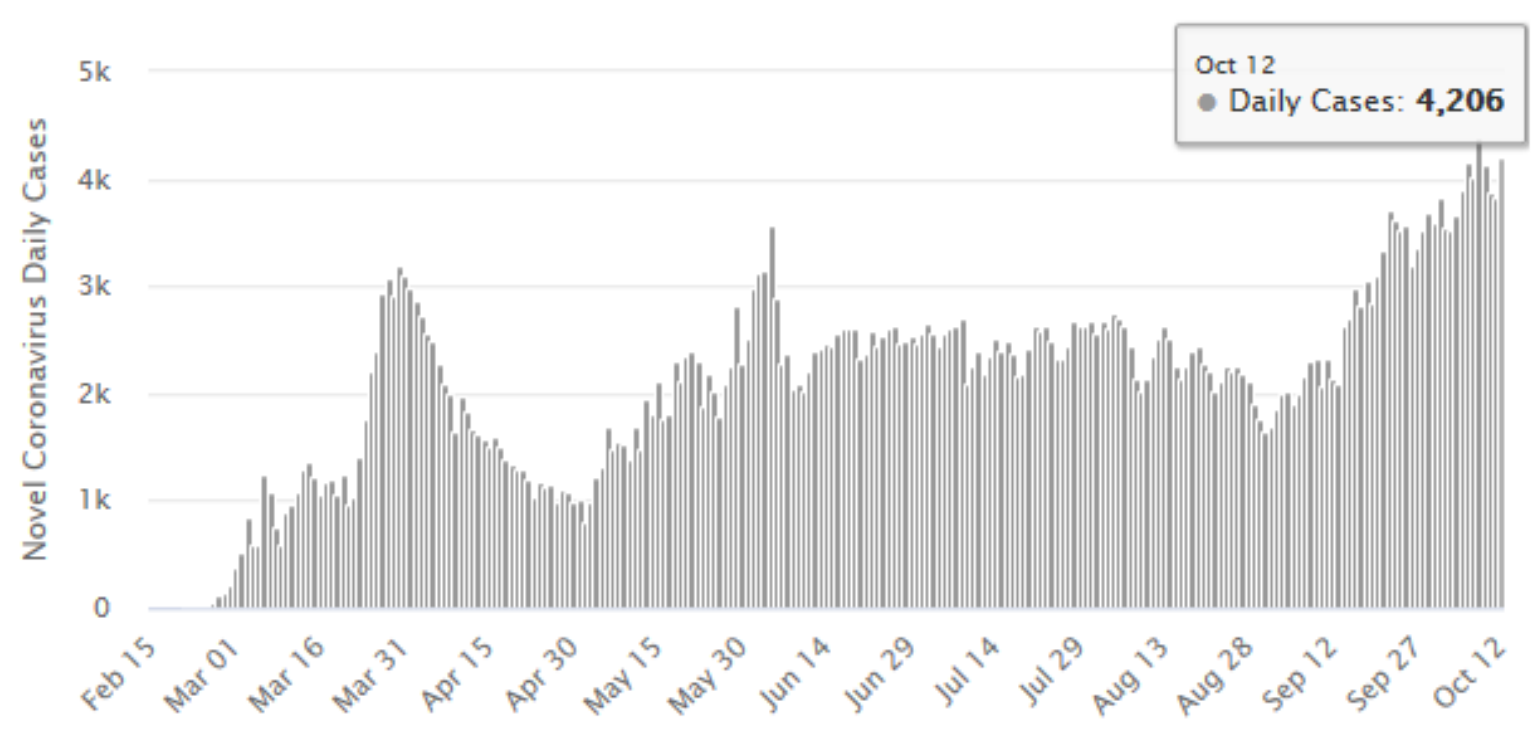

Figure 1. Fluctuations of daily new infected people in Iran due to COVID-19 disease during February $15^{\text {th, }}$ 2019- October $12^{\text {th, }} 2020$

Reference: WHO, countries, Iran Accessible on line at https://www.who.int/emergencies/diseases/novel-coronavirus

As you can see in the curve, according to official statistics, the number of new patients has been increasing despite the ups and downs. For example, 3186 people were infected daily at the end of March 2019. Unfortunately, this number has reached 4206 infected people on $12^{\text {th }}$ October 2020. An increase of approx. $31 \%$ of daily patients is the fact of failure in protecting public health. Our field observations show that polluted environment and sewages in the cities and villages are also the cause of the spread of COVID-19 disease. See also scholars like Barcelo, who are agreeing with our experiences [19]. Wastewaters' collection and treatment are major tasks of urban authorities, but they failed to fulfill their tasks. Planning and design techniques of wastewaters collecting infrastructure shall be done in the early process of urban master planning or revising the previous master plans [20] and [21]. We may choose one of the following options to collect and treat the wastewater aimed at protecting communities' health against COVID-19 disease and other sicknesses.

$\checkmark$ Waste Stabilization Ponds

$\checkmark$ Anaerobic Ponds

$\checkmark$ Facultative Ponds

$\checkmark$ Maturation Ponds

$\checkmark$ Constructed Wetlands

$\checkmark$ Up-flow Anaerobic Sludge Blanket Reactors

$\checkmark$ Bio-filtration

$\checkmark$ Aerated lagoons

$\checkmark$ Oxidation ditches 
Wastewater shall be collected in underground pipes (sewers). It shall not be left in open spaces! The flow in sewers is normally by gravity, with pumped mains only being used when unavoidable. From the infrastructure economics point of view, such projects are extremely expensive. The infrastructure design methods that require a centralized reactor for a whole metropolitan need huge investment. However, we have many lower-cost alternatives that are suitable for use in poor regions. From a civil engineering point of view, we recommend decentralized wastewater treatment in underdeveloped countries with economic problems. Various waste stabilization ponds have got anaerobic and photosynthetic technologies that use natural energies [22]. Mara analyzed technical, chemical, aerobic, organic, and executive characteristics of the above-mentioned techniques. Other scholars have worked with analyzing wastewater infrastructure collection and treatment technologies [23], [24], [25] and [26]. It is necessary to say that the choice of one or more techniques shall be based on the cognition of the site and the strategic goals of the area. To collect, treat, and even reuse wastewater and to have a healthy and clean environment, the climatic conditions, spatial design, and socioeconomic strategies of every city or region must be carefully analyzed.

\section{Applied methods and case studies}

Theoretical studies in the prior section aimed at shaping a guideline for the case studies. Both theoretical and case studies are looking for accuracy of our hypothesis that protecting individual and social health of communities against COVID-19 requires treatment of wastewater in the cities. Case studies are on wastewater analysis in Iranian cities and their effects on the spread of COVID-19 disease among the population. Iranian cities have a common feature that they almost do not have wastewater collection and treatment infrastructures. There are some exceptions like certain places for high-ranking officials, members of parliament, government officials and their affiliated capitalists, or the main street of each city beginning from the airport to the city administrative centers. Meanwhile, the majority of areas of cities are poor, marginal, and old neighborhoods with dense, polluted neighborhoods. In the neighborhoods, sewage is left on the streets. We analyze the origin of wastewater in the cities of Iran and its flow in the streets. We also explore the constituents of wastewater and its effects on public health. We examine wastewater collection and treatment methods that are suitable for the economic and climatic conditions of cities as well. Therefore, methodologies applied in this research are to analyze the effects of the crises caused by no treated wastewater in the communities. For this purpose, we present a mathematical model to show the increasing negative impacts of untreated wastewater through time passing. The model will have the ability to be simulated in every country/region. In our mathematical model, the death tolls in Iran caused by the COVID-19 disease during the period of $29^{\text {th }}$ August 2020 until $12^{\text {th }}$ October 2020 have been assessed. The studies show that the whole country of Iran experienced an increasing number of death tolls because of the 
unclean environment and particularly untreated wastewater in poor communities which is estimated to be majority of the Iran's population [27] and [28]. The sewage of Iranian cities, according to field observations, consists of two main parts.

1- Sewage from hospitals, livestock slaughterhouses, poultry farms, poultry slaughterhouses, car washes, traditional industry workshops, traditional commercial centers, which are usually dense and crowded markets with open sewage within, such as Figure 2.

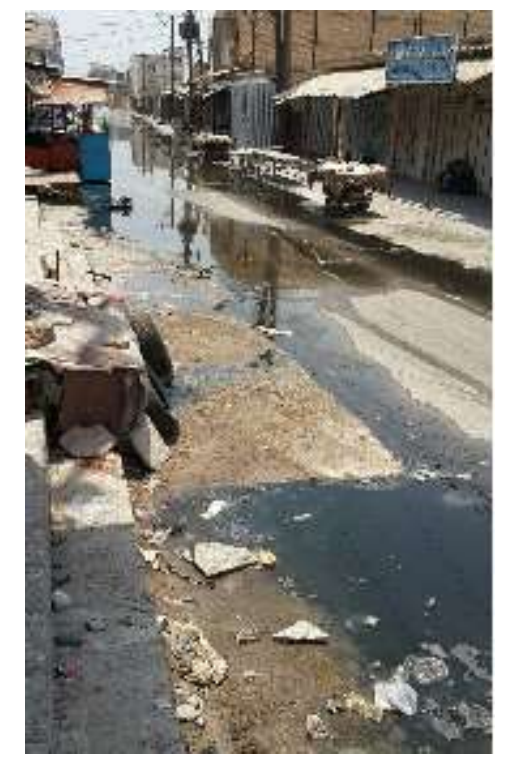

Figure 2. Sewage discharged in the commercial and market center of Iranian cities

2- Traditionally, absorption wells have been used to bury sewage in Iranian residential houses. With the passage of time and the congestion of residential houses in densely populated areas, those wells no longer have the capacity to absorb sewage. That is why people have left domestic sewage on the streets. This is not a difficult technique. Families pull only one pipe from inside the house into the street to discharge domestic sewage into the alley or street, as in Figure 3.

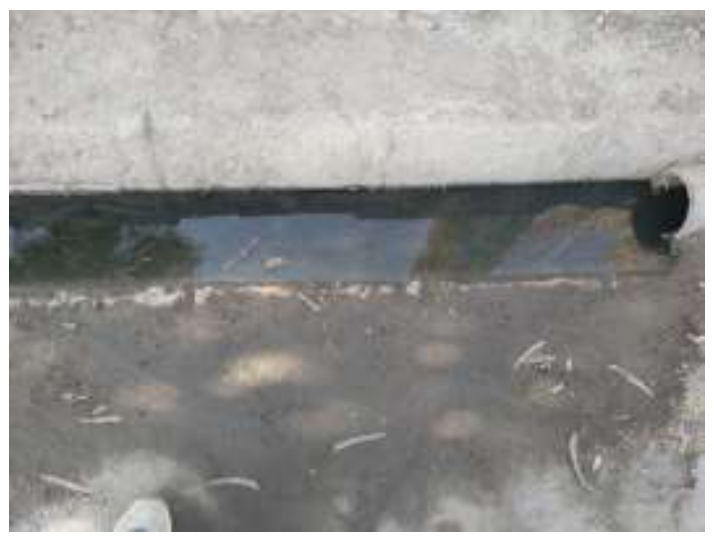

Figure3. A pipe connects household sewage to the street

Domestic sewage is produced in all residential households, inns, guesthouses, and hotels of Iran's cities. This sewage has water that has been used by the people and contains all the materials added to 
the water during various uses in the lives of the citizens. At the same time, large amounts of waste and plastic are seen in this wastewater. The sewages that have entered into the side waterways from the households through pipes then produce larger waterways located on allays and streets, as you can see in the pictures below.
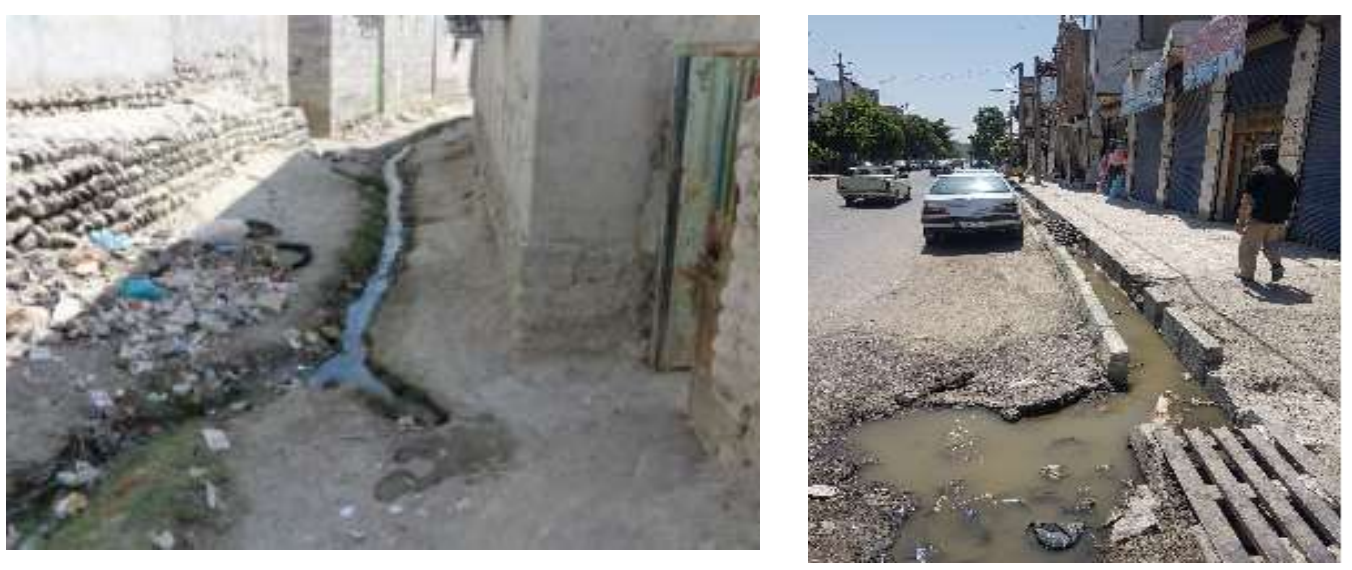

Figure 4. Sewages enter from homes into the creek in the middle of the alley and streets

The wastewaters then run to larger canals. The larger channels originally had a natural origin. In other words, the canals have been the natural water flow channels in Iranian cities, which have become narrower and smaller due to non-standard constructions in the bed of the natural seasonal rivers! See, for example, the image below.

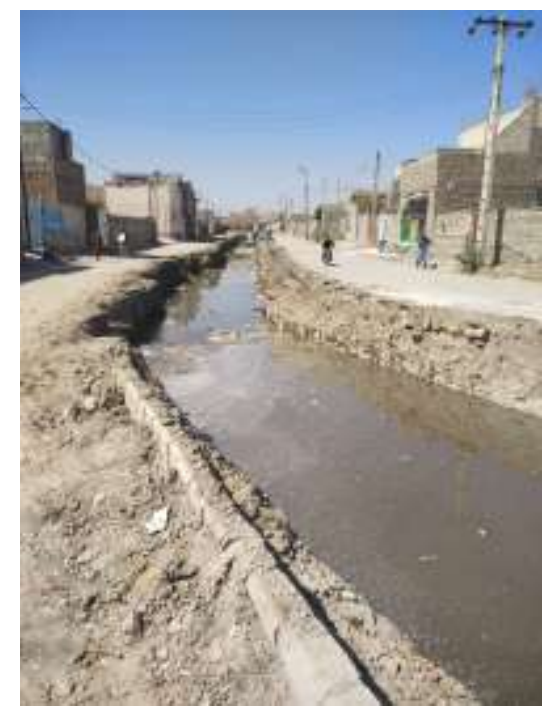

Figure 5. Joining small streams of sewage and pouring them into larger canals

The canals usually flow in the direction of the slope of urban lands. The volume of sewage in the canals increases due to the joining of more households' sewages. Of course, with the change of temperature in different seasons of the year, the volume of water in the sewage changes. Wastewaters in the lowlands with the formation of contaminated ponds are the source of traffic problems, bad smell, the birth of pests, and the spread of disease. See a sample in Figure 6. 


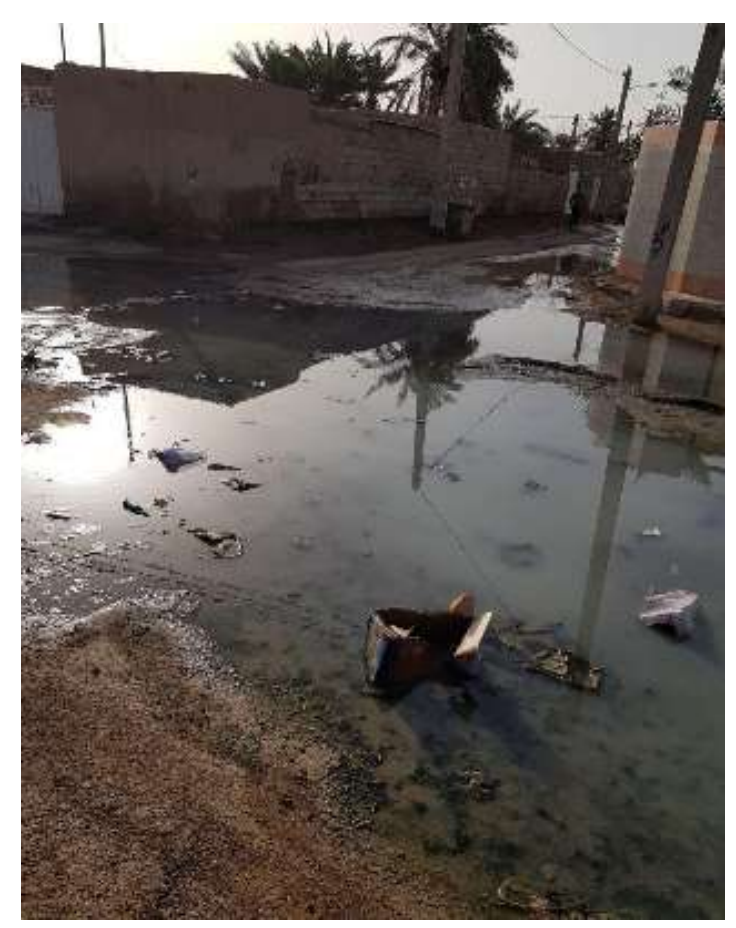

Figure6. An example of municipal and household wastewaters accumulated in the lowlands of Iranian cities and the formation of polluted ponds.

Sewage is not eye-catching in appearance and is objectionable. It is not intolerable. It is also dangerous to health. The presence of pathogenic organisms, especially the extremely coronavirus made the wastewater dangerous. Domestic sewage quickly loses its dissolved oxygen and becomes septic. Septic wastewater has an unbearable odor, usually due to hydrogen sulfide. Iranian cities need wastewater management and treatment for three reasons:

First, wastewater contains microorganisms that transmit diseases to humans in society.

Second, the impact of sewage on the biology of society, living things, and plants can cause the spread of COVID-19 disease from plants and animals to humans.

Third, it pollutes and degrades the environment, which has detrimental effects on the socioeconomic success of the cities.

\section{Model building}

We build a mathematical model to calculate the sum of death tolls due to the coronavirus and to predict the future trend of the disease pandemic. The death tolls during the time with the help of equation (1) have been calculated.

$$
\sum_{D T=1}^{n} f(D T)=\int_{m}^{n} f(D T) \cdot d t
$$

We calculate death tolls as

$D T_{1}-D T_{29}$

in 29 time points according to the following sum 


$$
\sum_{n=1}^{28} D T_{n}=\left(\begin{array}{l}
D_{1}, D_{2}, D_{3}, D_{4}, D_{5}, D_{6}, D_{7}, D_{8}, D_{9}, D_{10}, D_{11}, D_{12}, D_{13}, D_{14}, D_{15}, \\
D_{16}, D_{17}, D_{18}, D_{19}, D_{20}, D_{21}, D_{22}, D_{23}, D_{24}, D_{25}, D_{26}, D_{27}, D_{28}
\end{array}\right)
$$

Table 1. Daily death tolls in Iran from August $29^{\text {th }}$ until October, $12^{\text {th }} 2020$.

\begin{tabular}{|c|c|c|}
\hline $\begin{array}{l}\text { Day } \\
\qquad D_{n}\end{array}$ & Date & $\begin{array}{l}\text { Death tolls } \\
\qquad D T_{n}\end{array}$ \\
\hline 1 & Aug 29 & 110 \\
\hline 2 & Aug 31 & 109 \\
\hline 3 & Sep 02 & 125 \\
\hline 4 & Sep 03 & 125 \\
\hline 5 & Sep 05 & 139 \\
\hline 6 & Sep 08 & 132 \\
\hline 7 & Sep 10 & 129 \\
\hline 8 & Sep 12 & 116 \\
\hline 9 & Sep 14 & 156 \\
\hline 10 & Sep 16 & 179 \\
\hline 11 & Sep 18 & 144 \\
\hline 12 & Sep 20 & 183 \\
\hline 13 & Sep 22 & 178 \\
\hline 14 & Sep 23 & 184 \\
\hline 15 & Sep 25 & 207 \\
\hline 16 & Sep 26 & 172 \\
\hline 17 & Sep 27 & 195 \\
\hline 18 & Sep 29 & 207 \\
\hline 19 & Sep 30 & 183 \\
\hline 20 & Oct 01 & 211 \\
\hline 21 & Oct 03 & 179 \\
\hline 22 & Oct 04 & 211 \\
\hline 23 & Oct 05 & 235 \\
\hline 24 & Oct 06 & 227 \\
\hline 25 & Oct 08 & 230 \\
\hline 26 & Oct 09 & 210 \\
\hline 27 & Oct 10 & 195 \\
\hline 28 & Oct 11 & 251 \\
\hline 29 & Oct 12 & 272 \\
\hline
\end{tabular}

Reference: WHO, countries, Iran

Figure 7 exhibits well the rising death tolls from 110 daily deaths in the first point up to 272 deaths on $12^{\text {th }}$ October. 


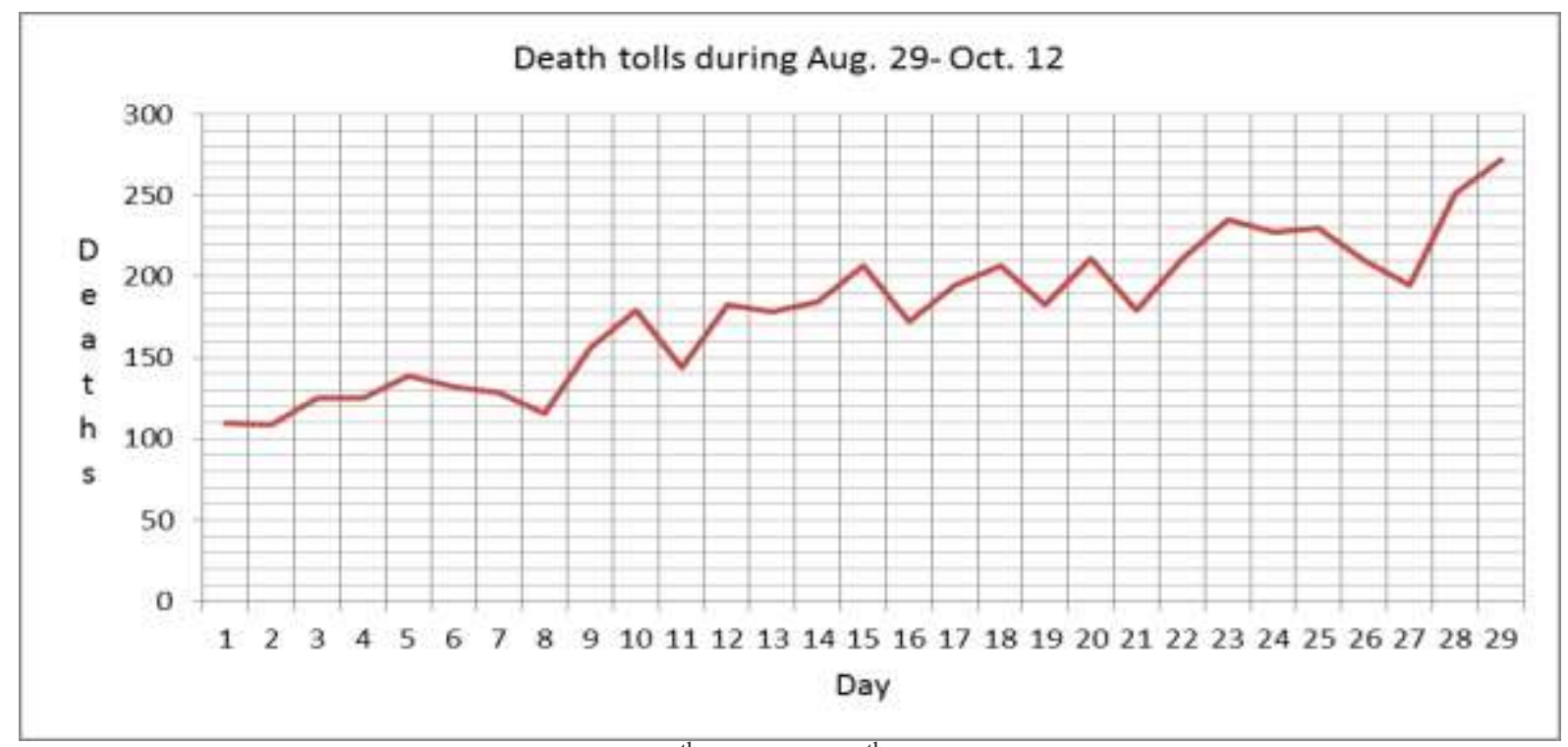

Figure7. Exhibits the rising death tolls in $29^{\text {th }}$ August- $12^{\text {th }}$ October

Figure 7 shows a worrying 149\% increase in daily mortality from coronavirus. The $149 \%$ daily increase in mortality is terrible. What should be done if the same trend continues in the coming weeks and months? We apply a statistical linear trend based on the following equation to forecast the future trend of the disease pandemic.

$$
\left\{\begin{array}{l}
f\left(D T_{n}\right)=4.7857 . d t+107.32 \\
R^{2}=0.8516
\end{array}\right.
$$

In equation (3), $R^{2}$ is the goodness-of-fit measure for our linear regression model. Figure 8 exhibits the trend line geometrically.

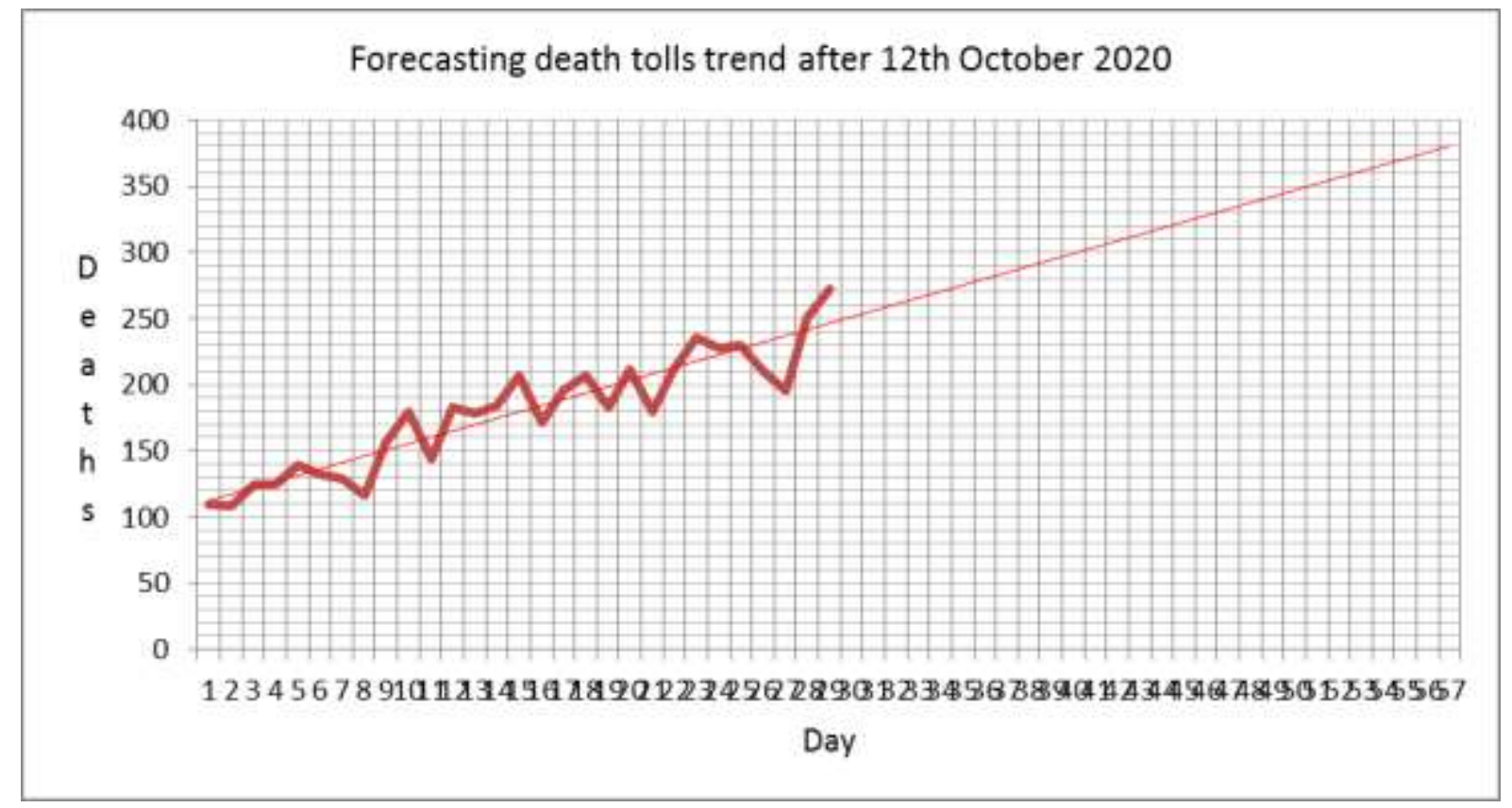

Figure8. Trend line exhibits the daily death trolls in coming weeks 
As you can see in the picture above, the trend line is, unfortunately, increasing with a steep slope, which is a warning sign of a human catastrophe. Therefore, if all the variables will be left as today, the COVID-19 disease is increasingly spreading and the catastrophe happens. As an essential solution way, wastewaters in the cities shall be managed, controlled, and treated. The risk of the spreading of the COVID-19 disease through the wastewaters shall be eliminated as soon as possible.

In some cities of Iran, the United Nations Urban Development Organization has called for the construction of modern sewage systems with the help of local authorities. However, due to structural corruption in urban management administrations, financial aid has been looted and projects have been left unfinished. The economic and climatic features of the cities shall be considered in every solution of the sewage problem in cities of Iran.

The first stage of wastewater treatment in Iranian cities, regardless of its type and applied technology, is the removal of large floating objects, plastics, pieces of wood, sands, etc. This action is necessary to prevent these materials from the surface of wastewater stabilization pools. Otherwise, floating air conditioners in aeration ponds or any pump in use may be damaged by the wastes. Separation of waste from wastewater in Iranian cities as the first step includes screening wastewater by installing sieves with appropriate sizes on the way to the wastewater treatment plant.

In cities of Iran with mostly hot and dry or temperate climates, domestic wastewater should be injected with oxygen so that the bacteria in it can consume the substances in the wastewater as their food. Equation (4) shows this process. In the process, the combination of oxygen and bacteria with sewage reproduces water as a product.

\section{Wastewater + Oxygen + Bacteria $\Rightarrow$ Treatedwastewater + newbacteria}

There are three solutions for injecting oxygen into the wastewater. Different amounts of oxygen shall be injected into the wastewater according to the quality and quantity of the wastewater and the purposes of its treatment:

1. Oxygen is required for oxidation of organic wastewater. This method requires some oxygen to oxidize the organic part of the wastewater and convert it completely to carbon dioxide and water. The method works according to Equation (5):

$$
\mathrm{C}_{6} \mathrm{H}_{12} \mathrm{O}_{6}+6 \mathrm{O}_{2} \Rightarrow 6 \mathrm{CO}_{2}+6 \mathrm{H}_{2} \mathrm{O}
$$

2. Oxygen required for chemical treatment of wastewater. This technique is done by oxidizing the wastewater by boiling it with an acidic dichromate solution.

3. Oxygen necessary for the treatment of wastewater by bacteria. This technique is done by oxidation of wastewater by bacteria. 
From a skeletal and physical design point of view, we recommend decentralized wastewater treatment plants for cities in Iran and similar cities. In general, important factors in designing a wastewater treatment system, including transmission lines, are:

- Percentage of productivity

- Reliability

- Sludge production

- Land requirements

- Environmental effects

- Operating costs

- Construction cost

- Stability

- Ease of operation, maintenance, and care

Decentralized wastewater treatment plants and water reuse should always be considered when planning urban land-use policies and physical design of cities because it can be an efficient and optimal procedure.

\section{Discussions}

As we have seen, having a clean environment, including the collected and treated wastewater, is vital to fight the coronavirus and to keep people healthy. Socioeconomic indicators in Iran show degradation in natural and urban environments, a decrease in the social capital of the government, a structural and institutionalized corruption in governmental institutions, an increase in social poverty and unemployment, and an increase in social revolts [29]. Economic sanctions and international pressures are also catalysts for now day's problems of Iran. For these reasons and widespread thefts with astronomical figures, the sewages in the cities have been abandoned. According to some government officials, a high percentage of Iranians cannot afford to buy masks, disposable gloves, alcohol, and disinfectants, visiting a doctor, and buy medicine [30]. As our field observations have shown, sewages have been dumped in cities, exposing people to a variety of diseases, including COVID-19. According to researchers at the Royal Institute of Technology, KTH, the coronavirus is present in municipal wastewater [14]. Therefore, wastewaters discharged in cities are accelerating the epidemic of this disease. Figure 1 exhibited that the number of daily new infected people in Iran on October $12^{\text {th }}$ compared to February $15^{\text {th }}$ increased by $31 \%$. Our concern is that with the polluted environment, this statistic will continue to rise in the coming months. Our mathematical model shows that between August 29 and October 12, 2020, the number of deaths due to this disease was increasing. The death tolls on October 12 were 272. Comparing this statistic with other countries respecting the number of population in every country, Iran ranks first in the world in terms of death 
tolls due to coronavirus. Note that these statistics are official that many researchers have got doubts about their validity. Many researchers estimate that the death tolls are three to five times higher [31] and [32]. It is also worrying concerning the prediction of the future death tolls that will be caused by the coronavirus. Our prediction through the statistical method of the trend line is alarming. Our forecast shows that the death statistics are going up and unfortunately Iran will experience many more deaths due to this disease in the coming months.

In our opinion, it is necessary to take action to collect, treat, and manage wastewater as soon as possible. Even responsible international organizations, due to the international connections of human beings, it is good to pay attention to this problem in Iran and similar countries.

As has been said, there are different methods of constructing wastewater treatment reactors with wastewater collection lines and infrastructures that create a centralized system for every city.

However, we think that decentralized systems are suitable for cities in Iran and developing countries. We recommend decentralized systems on the scale of every urban district. Decentralized models such as wastewater stabilization pools can use natural energies. They are also suitable for the economic and climatic conditions of the cities.

In planning and designing for wastewater collection and treatment systems in cities, indicators such as environmental cleanliness, urban landscape, construction and operation costs of reactors, efficiency, and durability of the system and, its economics should be considered.

\section{Conclusion}

This article discusses the presence of coronavirus in urban and domestic wastewaters. It was said that domestic wastewaters and sewages in the slums, which unfortunately includes the majority of people, has been left in allays, streets, and squares.

In this article, citing new sources, it was shown that the wastewater in such communities is the source of the spread of COVID-19 disease. The question addressed in this research was: can we stop the increasing spread of this disease without collecting, treating, and managing wastewater?

Our research methods were examining the latest opinions of world scientists, field studies, mathematical modeling, statistical techniques, forecasting of future, and dialectical reasoning. The findings of this study displayed the interconnectedness of the polluted environment, the uncollected, untreated, and unmanaged wastewater, and the increase in the number of COVID-19 diseases.

This article advises governments and city managers that the fight against the coronavirus should not be limited to hospitals and patient beds. Wastewater discharged into the streets and squares of cities must be collected, controlled, managed, and treated as soon as possible. This action destroys one of the centers of life of the coronavirus. The methods of this research and techniques to collect and treat wastewater can be simulated in any city anywhere in the world to fight COVID 19 disease. 


\section{References:}

Aaron, B., Devin, N., Arslan, A., Warish, A., Eric, A., Frederic, B., ... \& Gianluigi, B. (2020). Wastewater-Based Epidemiology: Global Collaborative to Maximize Contributions in the Fight Against COVID-19.

Amarasiri, M., Sano, D., \& Suzuki, S. (2020). Understanding human health risks caused by antibiotic resistant bacteria (ARB) and antibiotic resistance genes (ARG) in water environments: Current knowledge and questions to be answered. Critical Reviews in Environmental Science and Technology, 50(19), 2016-2059.

Arslan, M., Xu, B., \& El-Din, M. G. (2020). Transmission of SARS-CoV-2 via fecal-oral and aerosols-borne routes: Environmental dynamics and implications for wastewater management in underprivileged societies. Science of the Total Environment, 743, 140709.

Barcelo, D. (2020). An environmental and health perspective for COVID-19 outbreak: Meteorology and air quality influence, sewage epidemiology indicator, hospitals disinfection, drug therapies and recommendations. Journal of Environmental Chemical Engineering, 104006.

Brito, P. L., Kuffer, M., Koeva, M., Pedrassoli, J. C., Wang, J., Costa, F., \& Freitas, A. D. D. (2020). The Spatial Dimension of COVID-19: The Potential of Earth Observation Data in Support of Slum Communities with Evidence from Brazil. ISPRS International Journal of Geo-Information, 9(9), 557.

Capua, I. (2020). Circular Health: Empowering the One Health Revolution. EGEA spa.

Chastain Jr, J. R. (2004). A heuristic methodology for locating monitoring stations to detect contamination events in potable water distribution systems.

Cilliers, J., Oosthuizen, M., Alexander, K., Pooe, T. K., \& Moyer, J. D. (2020). Impact of COVID-19 in Africa: a scenario analysis to 2030. ISS Africa Report, 2020(24), 1-40.

Das, M. B., Khan, I. A., \& Tinsley, E. (2020). Results-Based Financing Through Social Enterprises: A White Paper for the Global Partnership for Results-Based Approaches, in Response to the Covid-19 Pandemic.

Fedorowicz, M., Schilling, J., \& Bramhall, E. (2020). Leveraging the Built Environment for Health Equity.

Foresti, E (2002) 'Anaerobic Treatment of Domestic Sewage: Established technologies and perspectives', Water Science and Technology, vol 45, no 10, pp181-186

Jedwab, R., Khan, A. M., Damania, R., Russ, J., \& Zaveri, E. D. (2020). Pandemics, poverty, and social cohesion: lessons from the past and possible scenarios for COVID-19. Mimeo.

Jethwaney, J. (2020). Covid-19 Disaster: Interdependence of Crisis Communication and SocioEconomic Resilience. In Disaster Management for 2030 Agenda of the SDG (pp. 333-358). Palgrave Macmillan, Singapore. 
Johnson, U. C. E. B., \& Trautman, L. J. (2020). The Demographics of Death: An Early Look at COVID-19, Cultural and Racial Bias in America. Cultural and Racial Bias in America (August 20, 2020).

Karki, M. (2020). Investigation of the factors enabling the development of medical waste treatment in Kathmandu, Nepal.

Kataki, S., Chatterjee, S., Vairale, M. G., Sharma, S., \& Dwivedi, S. K. (2020). Concerns and strategies for wastewater treatment during COVID-19 pandemic to stop plausible transmission. Resources, Conservation and Recycling, 105156.

Kraus, M. W., Park, J. W., \& Tan, J. J. (2017). Signs of social class: The experience of economic inequality in everyday life. Perspectives on Psychological Science, 12(3), 422-435.

Lahrich, S., Laghrib, F., Farahi, A., Bakasse, M., Saqrane, S., \& El Mhammedi, M. A. (2020). Review on the contamination of wastewater by COVID-19 virus: Impact and treatment. Science of The Total Environment, 142325.

Mara, D. (2013). Domestic wastewater treatment in developing countries. Routledge.

Marques, R. C., \& Miranda, J. (2020). Sustainable tariffs for water and wastewater services.

Mellish, T. I., Luzmore, N. J., \& Shahbaz, A. A. (2020). Why were the UK and USA unprepared for the COVID-19 pandemic? The systemic weaknesses of neoliberalism: a comparison between the UK, USA, Germany, and South Korea.

Mishra, R., Krishnamoorthy, P., Gangamma, S., Raut, A. A., \& Kumar, H. (2020). Particulate matter (PM10) enhances RNA virus infection through modulation of innate immune responses.

Environmental Pollution, 266, 115148.

Navarro, V. (2020). The Consequences of Neoliberalism in the Current Pandemic. International Journal of Health Services, 0020731420925449.

Paleologos, E. K., O’Kelly, B. C., Tang, C. S., Cornell, K., Rodríguez-Chueca, J., Abuel-Naga, H., ... $\&$ Goli, V. S. N. S. (2020). Post Covid-19 water and waste water management to protect public health and geoenvironment. Environmental Geotechnics, 1-15.

Pearson, H W, Mara, D D, Thompson, W and Maber, S P (1987a) 'Studies on High Altitude Waste Stabilization Ponds in Peru’, Water Science and Technology, vol 19, no 12, pp349-353

Proctor, C. R., Rhoads, W. J., Keane, T., Salehi, M., Hamilton, K., Pieper, K. J., ... \& Whelton, A. J. (2020). Considerations for large building water quality after extended stagnation. AWWA Water Science, 2(4), e1186.

Rahimiyan, R. (2020). Investigation of the Process of using Sludge Contaminated with Crude Oil in the Effluent of Chemical Industries. Progress in Chemical and Biochemical Research, 329-339.

Rusiñol, M., Martínez-Puchol, S., Forés, E., Itarte, M., Girones, R., \& Bofill-Mas, S. (2020). Concentration methods for the quantification of coronavirus and other potentially pandemic enveloped virus from wastewater. Current opinion in environmental science $\&$ health. 
Schellenberg, T., Subramanian, V., Ganeshan, G., Tompkins, D., \& Pradeep, R. (2020). Wastewater discharge standards in the evolving context of urban sustainability-The case of India. Frontiers in Environmental Science, 8, 30.

Tran, H. N., Le, G. T., Nguyen, D. T., Juang, R. S., Rinklebe, J., Bhatnagar, A., ... \& Chao, H. P. (2020). SARS-CoV-2 coronavirus in water and wastewater: A critical review about presence and concern. Environmental Research, 110265.

van Barneveld, K., Quinlan, M., Kriesler, P., Junor, A., Baum, F., Chowdhury, A., ... \& Friel, S. (2020). The COVID-19 pandemic: Lessons on building more equal and sustainable societies. The Economic and Labour Relations Review, 31(2), 133-157.

W A (1993) 'Occurrence and Removal of Cryptosporidium spp oocysts and Giardia spp Cysts in Kenyan Waste Stabilization Ponds', Water Science and Technology, vol 27, no 3-4, pp97-104

Wilkinson, R., \& Pickett, K. (2020). The inner level: how more equal societies reduce stress, restore sanity and improve everyone's well-being. Penguin Books.

World Bank. (2020). Resilient Water Infrastructure Design Brief.Thevenon, F. (2017). Sustainable Sanitation Systems: Health, Environment and Governance Challenges-The Case of Human RightsBased Policy Reform in Alternative Wastewater Management Strategies.

Yong, E. (2020). How the pandemic defeated America. The Atlantic, 4.

Zimmo, O R (2003) Nitrogen Transformations and Removal Mechanisms in Algal and Duckweed Waste Stabilization Ponds, PhD thesis, International Institute for Infrastructural, Hydraulic and Environmental Engineering, Delft 